\title{
Liberalization of Utility Services in the Developing Countries: A Panacea to Economic Development? An Analysis on Malawi Power Sector
}

\author{
Byson B. Majanga ${ }^{1}$ \\ ${ }^{1}$ Accountancy Department- The Malawi Polytechnic, University of Malawi, Malawi \\ Correspondence: Byson B. Majanga, Accountancy Department-The Malawi Polytechnic, University of Malawi, \\ Malawi.
}

Received: June 3, 2015

Accepted: June 18, 2015

Available online: July 14, 2015

doi:10.11114/aef.v2i3.853

URL: http://dx.doi.org/10.11114/aef.v2i3.853

\begin{abstract}
Economic development is a compound outcome arising from a combination of many factors which may include among others, good governance; educational levels of the citizenry; effective political and administrative systems; availability of production resources; as well as availability of utilities such as reliable electricity and clean and potable water.

Holding all other factors constant, the paper discusses the impact of reliable accessibility of utilities on economic growth and whether it is necessary or not to privatise or liberalise the utility sector, especially the electricity sector to enhance power access in promoting economic growth in developing countries like Malawi. Most developing countries in Africa face a lot of challenges in power generation and supply and the paper is focusing on establishing whether these challenges are a significant cause for stunted growth in GDP per capita in these countries, and whether liberalisation could be a way out of persistent power shortages affecting the economy.

The study findings reveal that there is a direct relationship between electricity consumption and growth in GDP per capita and that most developing countries struggling to improve their economies share the same challenge of power supply for effective productivity. The study further finds that liberalization of the power sector can invigorate the country's productivity and hence improve the GDP per capita.
\end{abstract}

Keywords: GDP per capita, liberalisation, privatisation, energy consumption, value addition.

\section{Introduction}

Human life is sustained with the presence of the basic amenities in life, the most common ones being clean water and electricity. The presence of clean and potable water to people in a country is key to good health and long life (assuming all other factors are constant), and good health is key to economic development in any nation. Electricity is a key to the operational effectiveness of the various industries since most, or all of the machines and equipment used in the industries are power driven. In the sub Saharan Africa, most of the power is generated through hydroelectric sources with a very little percentage from oil and natural gas sources (Eberhard, et al, 2008).

In the southern Africa region, most of the economic activities take place in the cities or towns as the rural residents simply engage in small scale farming for subsistence purposes since most of them lack access to electricity power for growth and development. This has caused a higher rate of urbanization recently where people leave the rural areas to live in the cities and towns to acquire jobs in the industries for their livelihoods. According to UN-Habitat, in some countries in the Sub Saharan Africa, rates of urbanization exceed four to five per cent per annum. However, the highly populated cities have not developed as expected in line with the commensurate economic growth and effective redistributive measures required to alleviate poverty of the masses.

Almost half of the people now live in cities, and according to the United Nations, (2005) it is estimated that within two decades, nearly sixty per cent of the world's people will be urban dwellers. Urban growth has and is being most rapid in the developing countries, where it is estimated that its population grows by two people per second.

As every person requires the basic necessities of water and electricity, the increasing population in the cities is piling up pressure on the existing facilities which were initially designed to cater for a very small number of people. In terms of electric power, it is estimated that the entire Sub Saharan Africa generates only 68 Gigawatts of electricity with 40 Gigawatts coming from South Africa alone (Eberhard, et al, 2008). The per capita demand for electricity in the same 
region is estimated at $155 \mathrm{KWh}$ and it is estimated to grow at the rate of ten percent per annum to cater for the urban population growth experienced in the latter days (Bazilian, et al, 2012). This growth rate in electricity demand per capita calls for increased generation to cater for the increased population.

\section{Literature Review}

\subsection{Electricity and Economic Development}

Research has shown that there is a direct relationship between electricity consumption and economic development. According to Adebola, 2011, electricity consumption is positively associated with real gross domestic product in the long run and in another study, Jebran, 2013, concluded that increase in electricity generation can enhance economic growth over long period of time and as such electricity deficient countries should have in place various policies for improvement of the electricity sector.

A number of studies have also been conducted on African countries to establish the relationship between electricity consumption and economic growth. Akinlo, (2009), and Johansen \& Juselius, (1990), investigated the causality relationship between energy consumption and economic growth for period 1980-2006 in Nigeria. The results showed that real gross domestic product and electricity consumption are directly related and that there is causality link running from electricity consumption to real gross domestic product.

Kouakou, (2011) investigated the causal relationship between the electric power industry and the economic growth of Cote d'Ivoire using the data from 1971 to 2008 . His findings revealed a direct link between per capita electricity consumption and per capita gross domestic product in the short run; and between electricity to gross domestic product in the long run. In Tanzania, an analysis of data for the period from 1971 to 2006 by Odhiambo, (2000) revealed a strong and stable long run relationship between energy consumption per capita and economic growth.

Another study by Jumbe, (2004) examined relationship between electricity consumption and respectively, overall gross domestic product, agricultural gross domestic product and non-agricultural gross domestic product using Malawi data for period 1970-1999. The results suggested that electricity consumption is respectively, co integrated with gross domestic product and non-agricultural gross domestic product, the causality tests suggested bidirectional causality between electricity consumption and gross domestic product.

The relationship between electricity consumption and economic growth, (measured by GDP), following historical trends for 1971 to 2007 , is shown in the graph below. The data for GDP is in US\$ per capita and electricity consumption (EC) is in kilowatt hours per capita converted in US\$.

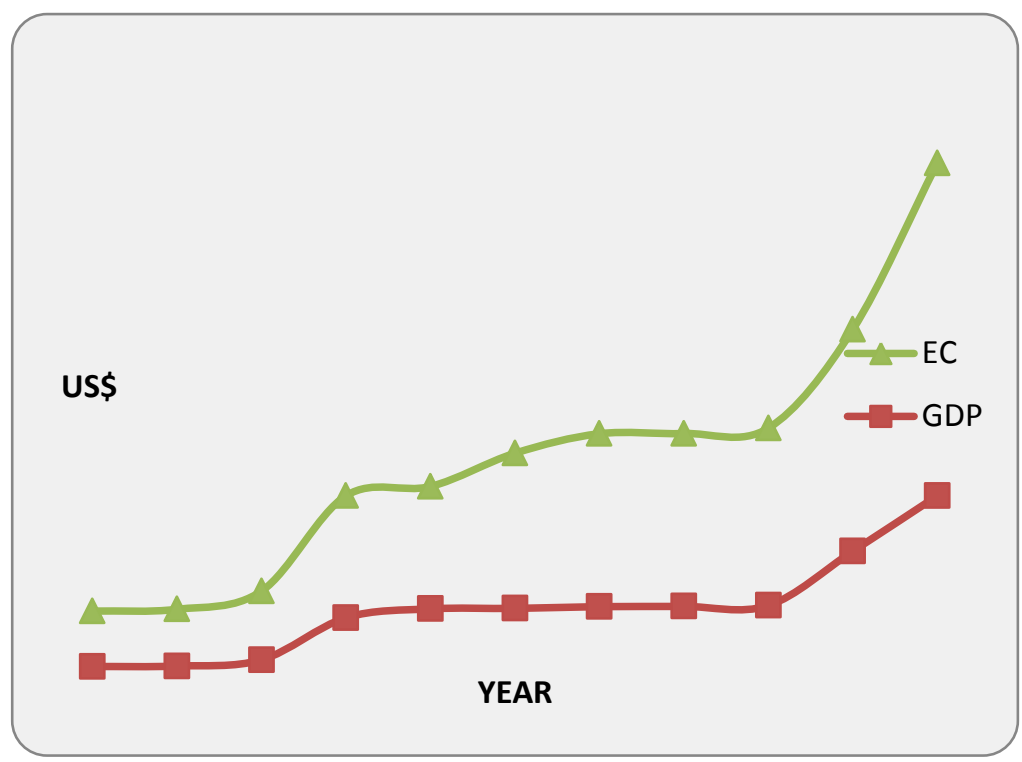

Figure 1. Relationship between Electricity consumption (EC) and Gross Domestic Product (GDP)

Source: Jebran, (2013)

\subsection{Privatization and Liberalization of the Power Sector}

Most companies in the power sector are state owned, and the proportion of the state's control in the power sector in the Southern part of Africa as depicted by Eberhard, (2001) is shown in figure 2 below: 


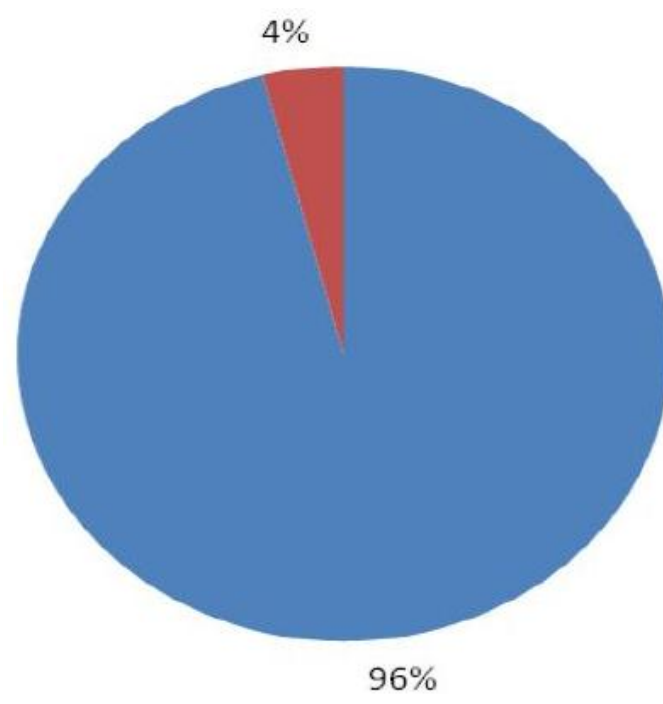

state owned

Private

Figure 2. Composition of actors in the Power industry in Southern Africa Region

Source: Eberhard, (2001)

The higher concentration of the state's presence in the power sector has put the economic performance of the developing countries at the mercy of the government's efforts to improve the sector's performance and efficiency.

The political governments mostly controlling the affairs of the state in the southern part of Africa are therefore expected to invest heavily in the power sector if the region is to register a remarkable economic growth. Of late, the region has been struggling to get out of the dark ages due to failure to improve the power generation capacity to cater for the growing demand of power. In addition, power supply has been unpredictable in many African countries due to among others, wars across the continent which have left generation facilities damaged and transmission lines cut; most governments' failure to maintain the power generating facilities; and adding to that, many countries have been left with unreliable, aging equipment with little means of having them upgraded. Malawi is a prime example of a Southern African Country operating at below its installed capacity due to aging facilities.

On the international scene, there have been calls for countries to make reforms by way of de regularising their respective power sectors to allow competition among various players in order to ultimately improve efficiency in power generation and supply. According to Eberhard, (2001), the electricity market reforms have generally involved the commercialisation and corporatisation of public utilities; changes in the structure of the industry to increase competition; the creation of a set of electricity market trading mechanisms; increased private sector participation; and changes in regulatory oversight.

A number of utility institutions previously owned by government have been on the verge of being privatised following their reported unsatisfactory performance and inefficiencies. The table below shows a number of public utility institutions on the privatisation list by 2002 in some parts of Africa.

Table 1. Planned privatisations of public utility companies

\begin{tabular}{|c|c|}
\hline Country & Planned privatisation \\
\hline Burundi & $\begin{array}{l}\text { Privatisation minister reported in February } 2002 \text { that the privatisation of the National Water } \\
\text { and Power Distribution and Production Company (REGIDESO) was in an advanced stage. }\end{array}$ \\
\hline Nigeria & $\begin{array}{l}\text { World Bank assisted with establishing a regulatory framework for privatising the water sector } \\
\text { through a concession contract; in February } 2002 \text {, the government of Nigeria received a } 14 \\
\text { person delegation of potential investors in the water sector from the UK. }\end{array}$ \\
\hline Rwanda & $\begin{array}{l}\text { Management contract for the electricity and water utility, Electrogaz, scheduled to be } \\
\text { completed in } 2002 \text {. }\end{array}$ \\
\hline Uganda & $\begin{array}{l}\text { Ugandan water authority had a management contract with Suez subsidiary, Ondeo, with a view } \\
\text { to eventually establishing a lease arrangement separating responsibilities for operating the } \\
\text { water supply from developing the infrastructure }\end{array}$ \\
\hline Zambia & World Bank assisted with the privatisation of the Lusaka Water and Sewerage Company. \\
\hline Kenya & $\begin{array}{l}\text { World Bank developed plans for privatising water supply and sewerage in Mombassa and the } \\
\text { coastal region as well as providing technical assistance for the preparation of a privatisation } \\
\text { strategy for the Water supply and sewerage in Nairobi }\end{array}$ \\
\hline Malawi & $\begin{array}{l}\text { World Bank provided assistance for an assessment of the options for private } \\
\text { involvement in Blantyre and Lilongwe cities }\end{array}$ \\
\hline
\end{tabular}




\begin{tabular}{ll}
\hline Ghana & $\begin{array}{l}\text { Bids invited for two leases for the national water supply which had been divided into two } \\
\text { 'business units'; one lease to run for } 30 \text { years and one for } 10 \text { years. Private operators were } \\
\text { expected to be in place in March } 2003\end{array}$ \\
Tanzania & $\begin{array}{l}\text { In 2002, bids were received from Biwater (UK) and Gauff (Germany) for the } \\
\text { dollar-based contract. }\end{array}$ \\
Guinea-Bissau & Revised privatisation plans reported in 2002.
\end{tabular}
Source: Baylis, (2003).

According to Atkins \& Emehelu, (2014), privatization reforms are usually designed to stimulate competition and make the particular sector concerned a more financially viable and attractive environment for investment that can sustain itself without the need for government subsidization. Increased competition in the power marketplace offers consumers a number of viable alternatives for power supply and helps to stabilize prices through market forces.

A competitive market for generation and distribution helps to increase power volumes and improve reliability and coverage to satisfy growing domestic demands of emerging economies, particularly in rural areas. In addition, chances are high that in a privatized and unsubsidized power sector, investors' profits are higher which results in an increase in revenue collection through taxes thereby reducing the governments' costs by no longer subsidizing a failing power sector which is mostly associated with volatile price swings.

In their article, Artkins \& Emehelu, (2014), looked at some African countries namely Uganda and Nigeria which adopted the privatisation of the power sector and how the strategy worked or failed to improve the power sector.

In Uganda, privatisation efforts were implemented and the entire process became fully operational in 2012. As a result of the privatisation, it was discovered that inefficiencies, by way of transmission losses decreased from $38 \%$ to $26 \%$. This achievement aside, it was discovered that rural areas still remained largely without power as emphasis was placed much on the urban areas for financial benefits which outweighed the operating costs, unlike in rural areas where there were little financial benefits for the private operators.

In Nigeria, the Electric Power Sector Reform Act was enacted and it outlined a reform process to unbundle the state-owned power company, the National Electric Power Authority, into separate entities for generation, transmission and distribution. According to Okoro \& Chikuni, (2007), the power sector reforms in Nigeria were meant to bring about competition in the sector as was the case in the telecommunication sector, which in turn, would positively affect the masses in a number of areas such as increase in employment; reduction in crime rate, following a good number of youth getting employed; improved and efficient services; as well as reduced power tariffs.

Much as privatisation of public entities stirs heated debates from all corners of the society, the issue of liberalisation of a particular sector on a local economy is also a controversial one. According to Rafael, et al, (2014), advocates of trade liberalisation argue that the system is good for the improvement of service provision and allows a symmetrical flow of information within the sector to all the individual players unlike where there is high government regulation cemented by political interference. The International Energy Agency, (2005) highlights one of the important benefits of electricity liberalisation to be the significant decrease in electricity rates for the industry participants. As liberalisation breeds perfect competition, industry players strive to provide good quality and efficient services to consumers who have a final command on the price of the service. It is argued that in a liberalised sector, industry players are price takers and not price makers and therefore price reduction becomes one of the fronts on which the players compete to retain their customers.

In Australia, electricity reforms were adopted in the early 1990s; Denmark in 1999, and Norway in 1992. The table below shows the reduction in electricity prices arising from liberalisation for three major industrial nations:

Table 2. Electricity costs paid by industry consumers (in US $\$ / K W h$ )

\begin{tabular}{llll}
\hline Year & Australlia & Denmark & Norway \\
& US\$/KWh & US\$/KWh & US $\$ /$ KWh \\
1978 & 0.080 & 0.081 & 0.080 \\
1980 & 0.070 & 0.077 & 0.080 \\
1982 & 0.072 & 0.044 & 0.010 \\
1984 & 0.072 & 0.040 & 0.090 \\
1986 & 0.060 & 0.050 & 0.080 \\
1988 & 0.065 & 0.054 & 0.065 \\
1990 & 0.064 & 0.060 & 0.065 \\
1992 & 0.060 & 0.061 & 0.063 \\
1994 & 0.059 & 0.050 & 0.058 \\
1996 & 0.060 & 0.058 & 0.040 \\
1998 & 0.040 & 0.040 & 0.050 \\
2000 & 0.038 & 0.040 & 0.050 \\
2002 & 0.038 & 0.051 & 0.050 \\
2004 & 0.040 & 0.050 &
\end{tabular}

Source: International Energy Agency (2005) 


\subsection{Electricity Generation, Supply and Demand in Malawi}

In the World Bank's Policy Research Working Paper, Lea \& Hanmer, (2009) explain Malawi as a landlocked, densely-populated country in Southern Africa where per capita annual income currently stands at around US\$290. Its population is highly rural with an increasing rate of urbanisation; agricultural production is predominately subsistence; and with little industrialisation hence low productivity. Malawi has not benefited from significant mineral endowments, and it mostly depends on finished goods products produced from neighbouring and other foreign countries.

The electricity sector in Malawi generates electricity mainly from hydro potential but thermal (mainly diesel and gas based) and small photovoltaic systems are also in use (Gamula, Liu, \& Peng, 2013). A significant number of commercial and industrial enterprises have installed their own diesel and petrol operated generators due to unreliable energy supply from the national energy supply utility company, but it is still a challenge to determine the capacity of such due to gaps in regulations.

Electricity Supply Corporation of Malawi (ESCOM) Limited is the only electrical power supplier and it is a publicly owned company which was established by an Act of Parliament in 1957 which was revised in 1963 and then 1998. The current total installed capacity of ESCOM is about $302 \mathrm{MW}$, of which $94 \%$ is generated by hydropower and the remaining $6 \%$ is thermal. Owing to the aged equipment, the electricity network is not in very good condition, resulting in substantial losses on the transmission and distribution networks of about $18 \%-22 \%$ of the already insufficient generated electrical energy.

By, and from the year 2000, ESCOM's total installed capacity had been 284 Megawatts while electricity demand by both individual and industrial consumers had been increasing above this and it is expected to increase to 829 Mega watts by the year 2020 (Malawi Government Annual Economic Report 2012).

This challenge of electricity generation and supply by ESCOM has had a significant negative effect on agricultural productivity as well as other industries in production, hence the consumers' reliance on foreign products.

\section{Research Methodology}

The study was conducted through primary research using structured questionnaire. The researcher followed basic procedures that are employed when developing the Likert scale questionnaire to assess the impact of unreliable and intermittent electricity on productivity in the commercial industrial sectors of Malawi. The formulated statements on the structured questionnaire were based on procedures recommended by Saunders, et al. (2009). The main steps that were followed when formulating the questionnaire included the identification and establishment of electric power dependency by industry stakeholders within a Malawian context, deviations from production targets arising from power blackouts, careful review of literature on the topical area, and insights gained from an examination of latest information gathered through the internet.

All these culminated into the formulation of the statements that represented main variables of the study as summarised in Table 3 below.

\subsection{Data Collection}

Empirical data were collected by means of a survey. The results were used for an empirical analysis of the research findings. A structured questionnaire was designed, guided by the research aims. The questionnaire focused on variable statements that would evaluate the impacts of inadequate and intermittent power supply on productivity from Malawian industry captains' point of view.

The researcher surveyed sample of businesses operating in the City of Blantyre, which is a major industrial and commercial capital of Malawi. The researcher is of the opinion that the views obtained from this sample reflect the view point of the majority of the businesses in Malawi as a nation.

\subsection{Questionnaire Structure}

To make the questionnaires user-friendly, the researcher formulated statements whose response would require the respondent to agree or disagree with a particular statement based on the Likert-style rating scales with the rankings signifying the degree of agreement ranging from a scale of " 1 " referring to "Strongly Disagree" to a scale of "5" referring to "Strongly Agree" on a five-point rating scale of the structured questionnaire. A five-point scale was used to assess validity as to the extent of agreement on each statement. In Likert scales, it is assumed that all participants will perceive "Strongly Agree" as expressing greatest favour or agreement towards the given statements than "Somehow Agree" and "Strongly Disagree" (Babbie, and Mouton, 2007; Saunders, et al., 2009; Welman, et al., 2005). The same order of response categories was maintained so as not to confuse respondents, as recommended by Dillman (2000). Industry captains were asked to rate their responses on the continuum scale that they were given. The questionnaire also assisted in the formulation of an objective and scientific report of the study findings. 


\subsection{Sampling}

The structured questionnaire was administered in hard copy format and was delivered to the respondents who were then followed up for any feedback.

Large and medium companies based in the city of Blantyre and involved in production and service delivery were randomly selected from those that are registered with the Registrar of Companies or Malawi Stock Exchange. The researcher also used a list of companies from the Malawi Confederation of Chambers of Commerce and Industry (MCCCI) which represents the private sector of Malawi; as well as a companies' list from the Malawi telephone directory that is prepared by the Malawi Telecommunications Limited (MTL) - this was appropriate especially for details of the medium-sized companies.

\subsection{Sampling Adequacy}

During data collection, a total of fifty six questionnaires were dispatched to various organisations from the commercial sector in the city of Blantyre, Malawi. Out of these questionnaires, thirty six responded to the questionnaire giving a final response rate of $64.3 \%$.

\section{Analysis and Discussion of Research Results}

Ratings on each statement were done through univariate analysis by using individual rating statistics and frequency tables. Overall, the analysis shows that there were varied responses from participants regarding the extent of their agreement on each of the questionnaire statements. This section reports on the study results and analysis of ratings on the questionnaire statements.

\section{Statement 1: Most operations are mechanised and rely solely on electricity power}

There seems to be a general consensus that production activities are too mechanical in nature and that without power supply, or with inadequate power supply (due to leakages, etc), very little or no production takes place. 83.3\% of the respondents agreed (22.2\% "Agree", 61.1\% "Strongly Agree"). Only 11.1\% somehow agreed and 5.6\% of the respondents disagreed with this statement. The analysis thus indicates that most production operations rely more on electric power energy.

Statement 2: Actual production levels realised are usually below the targeted ones annually.

The study findings indicate a strong interdependence between electricity and production levels in quantity. A total of $83.3 \%$ agree (44.4\% "Agree" and $38.9 \%$ "Strongly agree") with the above statement, while only $5.6 \%$ disagree and $11.1 \%$ "Somehow agree". The analysis demonstrates that most production businesses are constrained in their operations as most of their capacity is underutilised due to power failures. The recognition of this interdependence of output and power availability in production entities conforms to the findings of Adebola, (2011) where he established that electricity consumption had a positive and direct relationship with GDP per Capita in Botswana.

Statement 3: Production costs increase due to underutilisation of equipment during power outages.

In poor economies like Malawi, where the GDP per capita was reported to be at about US\$290 by 2008 with a sluggish growth in its economy (Lea \& Hanmer, 2009), the demand for some products is price inelastic due to lack of substitutes owing to few entities involved in production. This price inelasticity causes manufacturers to charge higher prices to take advantage of the consumers' situations and thereby make the consumer pay for the inefficiencies arising from the underutilisation of equipment due to power failure.

To the producers, the study has shown that the under utilisation of capital assets impact greatly on the production cost and this burden is fully born by the consumers following the price inelasticity of consumption demand.

The results show that $94.4 \%$ of the respondents agree that power failure causes the entities to operate below capacity and hence production costs increase as a result of under absorption of fixed costs. No respondent disagrees with the statement, while 5.6\% "Somehow agree". The findings demonstrate that the presence of expensive products in developing countries like Malawi could be countered and cushioned by increasing the power supply to the production sectors.

Statement 4: Power failures arise due to inefficiencies from government owned power company (ESCOM).

As highlighted in figure 2 above, Malawi's power sector is mostly operated by a government owned institution called the Electricity Supply Cooperation of Malawi (ESCOM) and a very little proportion by the private sector, mostly through solar energy. The study also aimed at establishing whether power generation and supply problems are totally out of government failure to operate the power company. The research findings show that a total of $69.5 \%$ of the respondents agree (47.3\% "Agree" and 22.2\% "Strongly agree") that power problems in Malawi arise due to government failure to run, manage and finance the sole electricity power generator and supplier under its ownership. Only $11.1 \%$ disagree, while $19.4 \%$ "Somehow agree" with the above statement. 
These research findings indicate that most organisations involved in production believe that the involvement of government in the operations of the ESCOM is responsible for the power supply challenges and ultimately low productivity in Malawi.

Statement 5: Malawi's sole power institution (ESCOM) must be privatised to improve its efficiency

The study showed that a majority of $61.1 \%$ agreed with the statement that the sole power institution in Malawi must be privatised to be run by private operators as a business entity to improve the institution's efficiency. Only $16.7 \%$ disagree and 22.2\% "Somehow agree" with the statement. The research findings together with some literature on privatisation of public entities indicate that most manufacturers, and in some cases individuals, recognise the need for politically uninterrupted power supply to enhance productivity and hence growth in GDP.

The research findings on this statement however are not in perfect tandem with the findings of other researchers. Bamenjo, (2002) found in his research that much as private operators improve the efficiency in their generation and supply of electricity for industry consumption, they usually shun the rural areas due to limited financial and economic benefits which they acquire in the urban areas.

Statement 6: The government must liberalise the power sector to allow perfect competition in power generation and supply.

The power sector in Malawi and other developing countries is structured in such a way that public institutions are in a monopoly leaving consumers with no choice but to access power supply from those institutions. The very few private operators are highly regulated such that they only provide solar and wind run power which is used only for limited domestic purposes and not sufficient enough for industrial purposes.

This statement was aimed at ascertaining whether or not the power sector should be fully liberalised to let other private power generators and suppliers offer an alternative to industries in accessing energy. A vast majority (83.3\%) of respondents agree (50\% "Agree" and 33.3\% "Strongly agree") that there is need for the power sector in Malawi to be liberalised. Only $16.7 \%$ "Somehow Agree" while $0 \%$ of the respondent disagree with the above statement. This analysis demonstrates that most power consumers prefer an open and liberal environment to have power institutions in a perfect completion to improve efficiency in power production and supply, hence consumer satisfaction.

The analysis of the six statements which made the core theme of the survey is summarised in Table 3 below:

Table 3. Statistical summary of the univariate analysis on the questionnaire statements

\begin{tabular}{lllllllll} 
& \multicolumn{10}{c}{ Rating } & scale \% & \\
Statement & SD & D & SHA & A & SA & Total & $\begin{array}{l}\text { Mean } \\
\mu\end{array}$ \\
\hline
\end{tabular}

1. Most of our operations are mechanised and rely on electric power 5.6

11.1 22.2

61.1 100

2. Actual production levels fall Below targeted levels annually $5.6 \quad 11.1$ 44.4 38.9 100

3. Production costs increase due to power outages

4. Power failures arise due to government inefficiencies

$\begin{array}{rrrrrrr}0.0 & 11.1 & 19.4 & 47.2 & 22.2 & 100 & 3.8 \\ 0.0 & 16.7 & 22.2 & 61.1 & 0.0 & 100 & 3.4\end{array}$

5. ESCOM must be privatised to improve efficiency

$\mathrm{N}=36$ to be liberalised to allow other

Key:

SD: Strongly Disagree (Ranking 1)

D: Disagree (Ranking 2)

SHA: $\quad$ Some How Agree (Ranking 3) 


\section{A: $\quad$ Agree (Ranking 4)}

\section{SA: Strongly Agree (Ranking 5)}

The Table 3 above indicates that Statement 1: "Most of our operations are mechanised and rely on electric power" has the highest mean $(\mu=4.4)$ on the response ratings seconded by Statements 2 and 6: "Actual production levels fall below targeted levels annually"; and "The Malawi power sector needs to be liberalised to allow other major players to operate", respectively, both with a mean $(\mu=4.2)$.

Overall, all the six statements show means that are above average $(\mu>3.0)$ signifying the above-average rankings that business' operations depend on electricity and that the overall industry productivity is a direct function of availability of sufficient and reliable power supply. The above average means also signify the business' owners sentiments towards the power sector in that the sector has to be reformed for the entities to have access to numerous and reliable power sources.

\section{Conclusion}

Any country's good economic performance depends on the value of goods or services which it produces every fiscal year and not necessarily how much the country consumes. The contemporary theory of production states that for production to take place, factors such as land, labour, capital and entrepreneurship are vital in the equation. With land which produces raw materials for production, entrepreneurs design ways of converting those raw materials into other products thereby adding value to the basic resources. The conversion of materials of value added products require the use of labour and to a great extent, capital equipment which require power to operate.

Quite a number of potential investors to Malawi have had their plans diverted to some other countries where electricity power is sufficient and reliable. Instead, they establish their plants elsewhere and acquire the raw materials from Malawi with which they produce products which are then sold back to Malawi at higher prices than that at which the raw materials were sold. The resultant effect in this scenario is that the country earns little foreign exchange in supplying raw and unprocessed products and spends more foreign exchange when importing the finished goods from elsewhere; resulting in a negative net export variable in the GDP equation.

The research findings have revealed that the few existing producers are not operating to their full capacity due to power shortages and in an attempt to recover their operating costs, they charge higher prices to the products making local products expensive than foreign ones, hence forcing locals consume more of foreign goods than local ones, effectively decreasing the import cover. Likewise, new investors shun the Malawi economy for fear of incurring unnecessary losses arising from the same problem. This could however be reversed if, according to the findings in this paper, the power sector in Malawi was to be liberalised, not necessarily privatising the government owned power company, but allowing other major operators to invade the power sector of the economy to supply to the producers the required energy at the same time competing with each other and focusing on the quality of services unlike in the current situation where power generation and supply is through a government owned monopoly, which by nature may not perform efficiently especially with the presence of political interference in its operations.

According to the research findings, the researcher does not fully advocate the privatisation of state owned power companies, in this case, ESCOM, as this would put the rural masses in more difficulties regarding power supply as private and commercial power operators mainly focus on supplying power to industries to enhance their revenue generation. The researcher suggests that ESCOM should remain a public institution but the playing field should be levelled to allow other players, after following right procedures, to offer the same services so that consumers, both individual and industrial should have a choice of where to access power for their domestic or production needs respectively.

The researcher feels that the study findings will facilitate the change of mindset by many business executives and government leaders on issues to do with power or energy situation in Malawi considering how it directly impacts on the economy; and focus on long term economic growth rather than short term which is normally and unfortunately a measure of success in political governments.

\section{References}

Adebola, S. (2011). Electricity Consumption and Economic Growth: Trivariate investigation in Botswana with Akinlo, A. (2009). Electricity Consumption and Economic Growth in Nigeria: Evidence from Cointegration and Atkins, K., \& Emehelu, I. (2014). Power Privatizations in Africa: Key Lessons. Project Finance. NewsWire.

Babbie, E., \& Mouton, J. (2007). The Practice of social research. Oxford University Press, Southern Africa: Cape Town.

Bamenjo, N. (2002). Energy Sector Privatisation in Africa: What Perspectives for Rural Electrification. Presentation to the Second International Conference: Energy for Sustainable 
Bayliss, K. (2003), Utility Privatisation in Sub-Saharan Africa: A Case Study of Water. Journal of Modern African Studies, 41(4), 507-531.

Bazilian, M., Nussbaumer, P., Rogner, H., Hammond, A., Foster, V., Pachauri, S., Williams, E., Howells, M., Niyongabo, P., Musaba, L., Gallachóir, B., Radka, M., \& Kammen, D. (2012). Energy access scenarios to 2030 for the power sector in sub-Saharan Africa. Utilities Policy. Elsevier Publications.Capital Formation. International Journal of Energy Economics and Policy, Co-Feature Analysis. Journal of Policy Modeling, 31(5), 681-693

Dillman, D. A. (2000). Mail and International Surveys: The Tailored Design Method. New York: Wiley.

Eberhard, A. (2001). Competition and regulation in the electricity supply industry in South Africa. Trade and Industrial Policy Strategies (TIPS) 2001 Annual Forum

Eberhard, A., Foster, V., Garmendia, C., Ouedraogo, F., Camos, D., \& Shkaratan, M., (2008). Underpowered: The State of the Power Sector in Sub-Saharan Africa. World Bank Report, Back ground paper .

Gamula, T., Hui, L., \& Peng, W. (2013) An Overview of the Energy Sector in Malawi. Energy Power and Engineering http://dx.doi.org/10.4236/epe.2013.51002.

International Energy Agency, (2005). Lessons from Liberalised Electricity Markets. OECD/IEA.

Jebran, K. (2013). Causal Relationship between Electricity Consumption and GDP in Pakistan. Journal of Asian development studies, 2(4), ISSN 2304-375X.

Johansen, S., \& Juselius, K. (1990). Maximum Likelihood Estimation and Inference on Cointegration with Application to the Demand for Money. Oxford Bulletin of Economics and Statistics, 52, 169-210.

Jumbe, C. (2004). Cointegration and Causality between Electricity Consumption and GDP: Empirical Evidence from Malawi. Energy Economics, 26, 61-68.

Kouakou, A. K. (2011). Economic Growth and Electricity Consumption in Cote d'Ivoire: Evidence from Time Series Analysis. Energy Policy, 39, 3638-3644.

Lea, N. \& Hanmer, L., (2009). Constraints to Growth in Malawi, World Bank Policy Research Working Paper 5097

Ministry of Economic Planning and Development, (2012). Malawi Government Annual Economic Report (2012), 49-50. November 2014. http://www.chadbourne.com/Power-Privatizations-in-Africa- Key- Lessons_projectfinance/

Odhiambo, N. M. (2009). Energy Consumption and Economic Growth Nexus in Tanzania: An ARDL Bounds Testing Approach. Energy Policy, 37, 617-622.

Okoro, O., \& Chikuni, E. (2007). Power sector reforms in Nigeria: Opportunities and challenges. Journal of Energy in Southern Africa, 18(3), 52-57.

Rafael, A., Vicente, S., Mahia, R., \& Medina, E. (2014). Trade liberalization and poverty reduction in Africa: Computable general equilibrium models approach. Literature review. International Journal of Political Science and Development, 2(5), 90-96

Saunders, M., Lewis, P., \& Thornhill, A. (2009). Research methods for business students. Prentice Hall:Edinburgh, England.Societies, Bogota, Colombia, 25-27.

UN-Habitat. State of the World's Cities: Trends in Sub-Saharan Africa Urbanization \& Metropolitanization, SOWC/04/RB/4 www.unhabitat.org

United Nations. (2005). Water and Urbanisation. http://www.un.org/waterforlifedecade/water_cities.shtml.

Welman, C., Kruger, F., \& Mitchell, B. (2005). Research methodology. Oxford University Press, Southern Africa: Cape Town.

\section{(cc) $\mathrm{BY}$}

This work is licensed under a Creative Commons Attribution 3.0 License. 